\title{
ANALISIS KANDUNGAN $\beta$-KAROTEN PADA JENIS SAWI PUTIH (Brassica pekinensia $L$ ) DAN JENIS SAWI HIJAU (Brassica Juncea $L$ coss) SECARA SPEKTROFOTOMETRI UV-VIS
}

\author{
Sukmawati Syarif, Milka Flaning \\ Fakultas Farmasi Universitas Muslim Indonesia \\ Email : sukmasyarif@gmail.com
}

\begin{abstract}
Analysis content of $\beta$-carotene for Sawi hijau (Brassica juncea $L$ coss) and sawi putih (Brassica pekinensia L) By Spectrophotometri Visible. A heve applied of research about contentof $\beta$-carotene in two quality of sawi namely sawi hijau (Brassica juncea L coss) and sawi putih (Brassica pekinensia L). For to Analysis and senelles content $\beta$-carotene in sawi. Sawi sample to be extraction in demarcation by acetone. The result of extraction to extract agein with petroleum eter and applied safonification with $\mathrm{KOH} 15 \%$. Qualitative analysis applied with Chromatography method in thin layer using petroleum eter:Benzen (9:1). The result it showing there are spot which same on two samples and $\beta$-carotene pure as the compere. While Quantitative analysis with spectrofotometri visible using $\beta$-carotene pure as compere showing that the content of $\beta$-carotene sawi hiaju $99,23 \mathrm{mg} / \mathrm{g}$ and sawi putih 40,91 $\mathrm{mg} / \mathrm{g}$.
\end{abstract}

Key Word : $\beta$-Karoten, Brassica pekinensia L, Brassica juncea $L$ coss

\section{PENDAHULUAN}

Dewasa ini masyarakat telah memanfaatkan kembali kekayaan alam seperti tumbuh-tumbuhan untuk kesehatan atau sebagai ramuan obat seperti yang telah dilakukan oleh nenek moyang kita. Salah satu pemanfaatan tumbuhan Indonesia adalah sebagai sumber vitamin. Vitamin merupakan zat pengatur yang meskipun jumlah yang dibutuhkan sangat sedikit tetapi harus ada agar sistim metabolisme tubuh dapat seimbang (Sedioetama, 1987 \& Linder,1992). $\beta$-karoten pertama kali diisolasi dari wortel, yang merupakan hidrokarbon larut dalam potrelum eter, eter,kloroform tetapi sedikit larut dalam etanol dan praktis tidak larut dalam air. Larutannya berwarna kuning, mengabsorbsi oksigen dari udara yang mempercepat terjadinya produk yang tidak aktif (Budavari,1989).

$\beta$-karoten adalah bentuk provitamin A paling aktif yang terdiri atas dua molekul retinol yang saling berkaitan. Karatenoid terdapat di dalam kloroplas tanaman dan berperan sebagai katalisator dalam 
fotosintesis yang dilakukan oleh klorofil (Almatsier, 2004).

Karoten merupakan provitamin A yang dalam tubuh akan diubah menjadi vitamin A. Vitamin A merupakan satu vitamin yang esensial untuk membantu pertumbuhan, kesehatan mata memelihara jaringan epitel dari keratinasi. Akibat yang paling parah karena kekurangan vitamin A adalah kebutaan, Mengingat karoten sangat besar perannya dalam proses penglihatan, maka ketersediaan karoten atau vitamin $\mathrm{A}$ dalam bahan pangan perlu diketahui (I Made Budi, 2005).

$\beta$-karoten tersebar dalam sayuran dan buah-buahan yang berwarna kuning atau hijau seperti pada wortel, Apricot, Selada, Sawi, Kubis, Bayam, Apel, Semangka, papaya, Ubi jalar, Tomat, Mangga, Cabei merah, dan beberapa bunga yang berwarna kuning dan merah (Winarno, 2000).

Pada bidang pertanian dikenal beberapa jenis sawi yaitu sawi putih (Brassica pekinensia L) dan sawi hijau (Brassica juncea $L$ coss). Sawi sebagai bahan makanan sayuran mengandung zat-zat gizi yang cukup lengkap sehingga apabila dikonsumsi sangat baik untuk mempertahankan kesehatan tubuh. Vitamin yang terkandung dalam Sawi adalah Vitamin A, Vitamin C, Thiamine (Vitamin $B_{1}$ ) dan Riboflavin (Vitamin $\left.B_{2}\right)$. Sedangkan mineral yang terkandung dalam Sawi adalah zat Besi (Fe), Fosfor (P), Kalsium (Ca) dan Natrium (Na). Kandungan gizi lainnya yang terdapat dalam Sawi adalah Protein, Lemak dan karbohidrat (Cahyono, 2003).

Keistimewaan Sawi dalam kandungan gizi terletak pada kandungan $\beta$-karoten yang cukup tinggi dibanding dengan jenis sayuran lainnya. Dengan demikian Sawi sangat baik untuk mengatasi dan mencegah penyakit rabun ayam (xerophthalmia) (Cahyono, 2003).

\section{METODE PENELITIAN}

\section{A. Waktu Dan Tempat Penelitian}

Penelitian

dilaksanakan pada Bulan April 2011 sampai selesai bertempat di laboratorium Fitokimia-Farmakognosi Fakultas Farmasi Univeritas Muslim Indonesia Makassar

\section{B. Alat dan Bahan}

Alat-alat yang digunakan : Aluminium Foil, corong pisah (Schott Duram), Gelas Ukur (Pyrex), labu erlemeyer (Pyrex), labu tentukur (Pyrex), neraca analitik (Sartorius), seperangkat alat kromatografi lapis tipis, 
seperangkat alat maserasi, spektrofotometer ultraviolet-visible (UV-VIS) (Shimadzu)

Bahan-bahan

yang digunakan : Air suling, asam sulfat (E. Merck), aseton (E. Merck), benzen (E. Merck), $\beta$-Karoten murni (Calbiochem), natrium sulfat anhidrat (E. Merck), metanol (E. Merck), kalium hidroksida (E. Merck), petroleum eter (E. Merck), sawi putih, sawi hijau.

\section{Prosedur Kerja}

\section{Penyiapan Sampel}

a. Pengambilan sampel

Sampel sawi
diperoleh dari salah satu
kebun masyarakat di desa
Malino Kabupaten Gowa.

b. Pengolahan sampel

Sampel

yang

diperoleh

dibersihkan

kemudian diambil daun dan batangnya, dipotong-potong kecil, diangin-anginkan lalu diamserasi dengan aseton.

\section{Penyiapan larutan Pereaksi}

\section{a. Pembuatan larutan $\mathrm{KOH}$} $15 \%$ b/v dalam metanol

Ditimbang 7,5 g KOH, dilarutkan dalam $25 \mathrm{ml}$ metanol hingga larut, kemudian dicukupkan volumenya hingga $50 \mathrm{ml}$ dengan metanol.

b. Pembuatan larutan Fase gerak

Petroleum eter : benzene (9:1) sebanyak 30 $\mathrm{ml}$ dengan cara mencampur $3 \mathrm{ml}$ benzene dengan $27 \mathrm{ml}$ petroleum eter dalam botol eluen, lalu dikocok hingga homogen.

\section{Ekstrak Sampel}

a. Sawi yang telah diberi perlakuan ditimbang sebanyak 50 g. Dimasukkan ke dalam wadah maserasi dan diekstraksi dengan 350 $\mathrm{ml}$ aseton.

b. Ekstrak aseton yang diperoleh dikisatkan kurang lebih $5 \mathrm{ml}$ kemudian diekstraksi kembali dengan petroleum eter sebanyak $3 x$ 25 ml. Hasil ekstraksi dikisatkan sampai kurang lebih $5 \mathrm{ml}$, kemudian dilakukan safonifikasi dengan menambahkan $\mathrm{KOH}$ $15 \%$ dalam metanol sebanyak $5 \mathrm{ml}$, dikocok dan diamkan semalam.

c. Hasil saponifikasi tersebut diekstraksi kembali dengan petroleum eter sebanyak $3 x$ 
$25 \mathrm{ml}$, lalu dicuci dengan air

suling sampai bebas basa,

lalu dikeringkan dengan

$\mathrm{Na}_{2} \mathrm{SO}_{4}$ anhidrat, kemudian

dicukupkan volumenya

hingga $100 \mathrm{ml}$ dengan

petroleum eter.

\section{Analisis Kualitatif}

Pembanding $\beta$-Karoten
murni dan sampel ditotolkan
bersama-sama pada lempeng
KLT. Setelah kering lempeng
KLT dimasukkan ke dalam
chamber kemudian dielusi
dengan menggunakan cairan
pengelusi petroleum eter :
benzene (9:1) selanjutnya
lempeng KLT dikeluarkan dari
chamber kemudian diamati
noda dengan lampu UV 254
nm.

5. Analisis Kuantitatif

a. Pembuatan Larutan Baku

1. Ditimbang teliti $25 \mathrm{mg} \beta$ Karoten murni, dilarutkan dengan petroleum eter hingga volume $100 \mathrm{ml}$ pada labu tentukur 100 ml. Diperoleh larutan dengan konsentrasi 500 bpj.

2. Dari konsentrasi 500 bpj kemudian dicukupkan volumenya hingga 100 ml. Dari larutan ini dipipet $1 \mathrm{ml}, 2 \mathrm{ml}, 3 \mathrm{ml}, 4 \mathrm{ml}$ dan $5 \mathrm{ml}$ dari larutan 500 bpj, kemudian dimasukkan kedalam labu tentukur dan dicukupkan volumenya hingga 100 ml. Diperoleh larutan baku dengan konsentrasi 5 bpj,10 bpj,15 bpj, 20 bpj, 25 bpj.

b. Penentuan

Panjang

\section{Gelombang}

Diambil salah satu konsentrasi bahan baku $\beta$ Karoten,kemudian diukur serapannya pada panjang gelombang 449.6nm menggunakan spektrofotometer.

c. Pembuatan Kurva Baku

1. Disiapkan larutan baku dengan konsentrasi 5,10,15,20, dan 25 bpj.

2. Masing-masing larutan baku tersebut diukur serapannya pada panjang gelombang $449.6 \mathrm{~nm}$.

d. Pengukuran Kadar $\beta$ Karoten dalam sampel

Dipipet dengan teliti 1 ml larutan sampel ke dalam labu tentukur $10 \mathrm{ml}$ dan 


$\begin{array}{lrl}\text { ditambahkan } & \text { larutan } & \text { serapannya pada panjang } \\ \text { potreleum eter hingga tanda } & \text { gelombang } 449.6 \mathrm{~nm} . \\ \text { garis dan } & \text { diukur }\end{array}$

\section{HASIL PENELITIAN}

Tabel 1 : Hasil Analisis kualitatif sampel sawi hijau dan sawi puth sacara Kromatografi Lapis Tipis (KLT)

\begin{tabular}{ccccccc}
\hline \multirow{2}{*}{ Penampakan Noda } & \multicolumn{3}{c}{ Nilai Rf } & \multicolumn{3}{c}{ Warna Noda } \\
\cline { 2 - 7 } & P & A & B & P & A & B \\
\hline \multirow{2}{*}{ UV 254 nm } & 0.4 & 0,4 & 0,4 & Kuning & Kuning & Kuning \\
& - & 0,18 & 0,21 & - & Kuning & Kuning \\
& - & 0,07 & 0,11 & - & Ungu & Ungu \\
\hline \multirow{2}{*}{ Visible } & 0.4 & 0,4 & 0,4 & Kuning & Kuning & Kuning \\
& - & 0,18 & 0,21 & - & Kuning & Kuning \\
& - & - & - & - & - & - \\
\hline
\end{tabular}

\section{Keterangan :}

$\mathrm{P} \quad=$ Senyawa Pembandinga $\beta$-karoten

A $=$ Sawi Hijau

$\mathrm{B}=$ Sawi Putih

Eluen $=$ Petroleum eter : Benzen $(9: 1)$

Tabel 2 : Hasil analisis kuantitatif $\beta$-karoten pada sawi hijau (Brassica juncea $L$ coss) dan sawi putih (Brassica pekinensia)

\begin{tabular}{cccccc}
\hline Sampel & Berat sampel $(\mathbf{g})$ & Serapan & $\begin{array}{c}\text { Kadar } \\
(\mathbf{m g} / \mathbf{g})\end{array}$ & $\begin{array}{c}\text { Kadar } \\
(\mathbf{m g} / \mathbf{1 0 0 g})\end{array}$ & $\begin{array}{c}\text { Kadar rata-rata } \\
(\mathbf{m g} / \mathbf{1 0 0 g})\end{array}$ \\
\hline \multirow{2}{*}{ Sawi Hijau } & 50,0020 & 0,502 & 0,9945 & 99,45 & \\
& 50,0018 & 0,501 & 0,9923 & 99,23 & 99,23 \\
\hline \multirow{3}{*}{ Sawi putih } & 50,0014 & 0,500 & 0,9902 & 99,02 & \\
& 50,0022 & 0,310 & 0,5850 & 58,5 & 40,91 \\
& 50,0032 & 0,326 & 0,6191 & 61,91 & \\
\hline
\end{tabular}

\section{PEMBAHASAN}

Pada penelitian ini digunakan jenis sawi hijau dan jenis sawi putih, untuk mengetahui kadar $\beta$-karoten-nya yang dilakukan secara spektrofotometri UV-visibel dan Kromatografi Lapis Tipis (KLT).

Penelitian ini dalakukan dengan cara mengekstraksi sampel secara maserasi dengan menggunakan cairan penyari aseton untuk mengekstraksi senyawa-senyawa organik yang terkandung dalam sempel. Setelah itu , senyawa karetenoid yang diinginkan dalam ekstrak aseton ditarik dengan menggunakan potroleum eter. Kemudian dilakukan proses safonifikasi atau penyabunan dengan menambahkan larutan $\mathrm{KOH} 15 \%$ dalam methanol untuk melepaskan ikatan esternya karena senyawa karetenoid dari bahan alam biasanya 
dalam bentuk ester. Dari hasil rekasi penyabunan tersebut terbentuk sabun dan bersifat basa sehingga sebelum dilakukan analisis lebih lanjut., ekstrak tersebut harus dibebas basakan dengan cara mencuci ekstrak dengan air suling sehingga rantai hidrokarbon yang bersifat hidrofob akan larut dalam petroleum eter sedangkan ion sabun yang bersifat hidrofilik akan larut kedalam lapisan air. Ekstrak petroleum eter yang diperoleh dikeringkan dengan cara penambahan $\mathrm{Na}_{2} \mathrm{SO}_{4}$ anhidrat untuk menarik air agar ekstraknya bebas dari air sehingga diperoleh hasil analisis yang lebih baik.

Pada analisis kulitatif, ekstrak petroleum eter jenis sawi hijau dan jenis sawi putih diuji secara Kromatografi Lapis Tipis (KLT) dengan menggunakan pembanding $\beta$-karoten murni dengan cairan pengelusi petroleum eter : Benzen $(9: 1)$ dimana dihasilkan bercak berwarna kuning pada masing-masing sampel dengan nilai Rf 0,4. Bercak dan nilai Rf yang diperoleh sama dengan senyawa pambanding $\beta$-karoten murni yang juga berwarna kuning dengan nilai $R f$ 0,4 . hal ini menujukkan bahwa sampel jenis sawi hijau dan jenis sawi putih yang dianalisis mengandung senyawa $\beta$-karoten.
Sedangkan pada analisis kuantitatif diperoleh kadar $\beta$-karoten pada sampel sawi jenis sawi Hijau yaitu $99,23 \mathrm{mg} / 100 \mathrm{~g}$ dan jenis Sawi putih yaitu 40,91 mg/100g, yang dilakukan secara Spektrofotometri UVVisible. Adanya perbedaan kadar dari jenis sawi Hijau dan jenis sawi putih tersebut disebabkan beberapa faktor diantaranya karena perbedaan jenis dan warna dari kedua jenis tersebut, dan faktor lainnya yaitu kondisi dan iklimnya.

\section{KESIMPULAN}

Berdasarkan hasil penelitian yang telah dilakukan, maka dapat disimpulkan sebagai berikut :

a. Sawi jenis sawi Hijau dan Sawi Putih Mengandung $\beta$-karoten

b. Kadar $\beta$-karoten dalam sawi jenis Sawi Hijau 99,23 mg/100g dan pada jenis Sawi Putih 40,91 $\mathrm{mg} / 100 \mathrm{~g}$.

\section{DAFTAR PUSTAKA}

Adnan, M., (1997), Teknik Kromatografi Untuk Analisis Bahan Makanan, Penerbit Andi, Yogyakarta.11.

Almatsier, S., (2004). Prinsip Dasar IImu Gizi Penerbit Gramedia Pustaka Utama, Jakarta, 158.

Andarwulan, N., Koswara S., (1992), Kimia Vitamin Penerbit Rajawali Press, Jakarta, 171-185 
Budivari, S., (1989), The Merc Index an Encyclopedia of Chemical and Biological, Merc and Co. Publishing. USA, 432-434.

Bambang Cahyono., (2003), Teknik Budi Daya dan Analisis Usaha Tani Sawi Putih Aneka IImu. Semarang, 1-2.

Bellaart, A. C., (1983), Ikhtisar Ringkas Vitamin dan Hormon Terpenting, Terjemahan, Jakarta, 5-7.

Budi I. Made. M.S., (2005), Fenomena Buah Merah, 14-15.

Harborne, J.B., (1997). Metode Fitokimia Penuntun Cara Modern Menganalisis Tumbuhan Edisi II, Terjemahan Kosasih Padmawinata, Penerbit ITB, Bandung, 157.

Linder C. M.,(1992), Biokimia Nutrisi \& Metabolisme Penerbit Universitas Indonesia, Jakarta, 178.

Sediaoetama D.A.,(1987), Vitaminologi, Penerbit Balai Pustaka, Jakarta, 103-105.
Suhardjo \& Kusharto M., (999). Prinsip-prinsip IImu Gizi. Penerbit Kanisius. Yogyakarta, 67.

Sastromidjojo H., (1985). Kromatografi. Liberty, Yogyakarta, 34-35

Sastromidjojo H., (1985). Spekroskopi. Edisi I, Liberty, Yogyakarta, 39

Solomons. G., (1980). Organic Chemistry, Second Edition, John Wiley and Sons, Inc. New York, 423-425

Sultary. R.,Kaseger B., (1985), Kimia Pangan, Badan Kerjasama Perguruan Tinggi Negeri Bagian Timur, Ujung Pandang

Winarno F.G., (2000). Kimia Pangan Dan Gizi, Penerbit Gramedia Pustaka Utama, Jakarta, 178.

Kus Irianto., Kusno W,, (2004). Gizi \& Pola Hidup Sehat. Penerbit Rama Widya, Bandung, 37. 